\title{
General Election and Stock Market Performance: A Malaysian Case
}

\author{
Faridah Najuna Misman ${ }^{1}$, Shashazrina Roslan ${ }^{1} \&$ Muhammad Izzat Mat Aladin ${ }^{2}$ \\ ${ }^{1}$ Department of Finance, Faculty of Business and Management, Universiti Teknologi MARA Johor Branch, Segamat \\ Campus, Segamat, Malaysia \\ ${ }^{2}$ Bachelor of Business Administration (Hons) Investment, Faculty of Business and Management, Universiti Teknologi \\ MARA Johor Branch, Segamat Campus, Segamat, Malaysia \\ Correspondence: Faridah Najuna Misman, Department of Finance, Faculty of Business and Management, Universiti \\ Teknologi MARA Johor Branch, Segamat Campus, 85000 Segamat, Johor, Malaysia.
}

Received: May 12, 2020

Accepted: June 20, 2020

Online Published: June 29, 2020

doi:10.5430/ijfr.v11n3p139

URL: https://doi.org/10.5430/ijfr.v11n3p139

\begin{abstract}
The 2018 Malaysia general election has marked a new history for the Malaysia political structure. After more than 60 years Barisan Nasional ruling the country, in the 2018 general election Barisan Nasional lose the game to the Pakatan Harapan. The results of the $14^{\text {th }}$ general election has caused a shock not only to political arena but also to the Malaysian financial market. Therefore, this paper aims to investigate if there is any significant effect of $14^{\text {th }}$ Malaysia general election on the Malaysia financial market specifically the stock market. Results from the statistical analysis reveal that there are significant changes in the Malaysia stock market performance after the $14^{\text {th }}$ general election.
\end{abstract}

Keywords: stock market performance, general election, political climate

\section{Introduction}

Over the years, researchers and practitioners have examined whether the political process and the stock market are interrelated. Studies on the relationship between politics and finance have been well documented. Empirical studies show that financial markets react calmly to political changes. As part of those research efforts, one of the most commonly analysed issues is whether the results of elections have any impact on stock market returns Abidin, Old, and Martin (2010); (Colón-De-Armas, Rodriguez, \& Romero, 2017; Floros \& Floros, 2008; Keef \& Roush, 2002; Liew \& Rowland, 2016; Oehler, Walker, \& Wendt, 2013; Waggle \& Agrrawal, 2018).However, there is very minimum studies focussing on Malaysian market. Therefore, this research aims to examine what is the impact of one of the major political events which is general elections on Malaysian stock market. There are few motivations behind this research. After closely examine the performance of stock market after $12^{\text {th }}$ and $13^{\text {th }}$ general elections (GE), the researchers found that, there is an opposite direction in the movement of stock market after $12^{\text {th }} \mathrm{GE}$ and $13^{\text {th }}$ GE. This situation poses an attention to the current studies to further investigate the impact of the latest $14^{\text {th }} \mathrm{GE}$ as the most recent GE $14^{\text {th }}$ result is shocking the political climate in Malaysia.

Kithinji and Ngugi (2009) claim that, there are numerous studies that have undertaken by the previous researcher that focussing on the relationship between political events and stock market performance. However, majority of the studies were carried out using a developed stock market as a sample. Malaysia is one of the countries that practise a parliamentary-system in ruling the country. As many previous studies focussing on stock market and political event in a presidential-system country (Abidin et al., 2010; Colón-De-Armas et al., 2017; Mattozzi, 2004), therefore this study uses Malaysia as a sample to examine the claim by Pantzalis, Stangeland, and Turtle (2000) that the reaction of stock market on the election may vary in different countries of different political climate, economics and press freedom.

\subsection{Malaysian Stock Market}

Stock Exchange of Malaysia (SEM) was first launched in 1964. In 1965, the Malaysian stock exchange has been restructured due to the separation of Singapore from Malaysia and was renamed into Stock Exchange of Malaysia and Singapore. After the currency interchangeability between Malaysia and Singapore ended in 1973, Stock Exchange of Malaysia and Singapore was separated into Kuala Lumpur Stock Exchange Berhad and the Stock Exchange of Singapore. In 1976, the Kuala Lumpur Stock Exchange took over the operations of the Kuala Lumpur Stock Exchange Berhad as a company limited by guarantee. After about 40 years of its existence, Malaysia stock exchange once again been rebranding into Bursa Malaysia Berhad in April 2004. This is due to the demutualization 
exercise in order to develop their attractiveness and to respond towards worldwide trends in the exchange sector by becoming more customer-driven and market-oriented.

To date, Bursa Malaysia is an exchange holding company as approved under Section 15 of the Capital Markets and Services Act 2007. It is a fully integrated exchange and offers a wide-ranging exchange-related services. For example, trading, clearing, settlement and depository services. Bursa Malaysia wholly owned 10 subsidiaries that operates in various businesses evolved around exchange related. Bursa Malaysia objective is to help in evolving Malaysia's capital market through growing competitiveness, and to maintain an efficient, secure and active trading market for both, local and global investors (Bursa Malaysia, n.d.). The main index in Bursa Malaysia is the FBMKLCI. FBMKLCI play an important role as key indicator for Malaysian stock market performance. Currently, the index is comprised of 30 companies in Malaysia as the main market capitalization.

\section{General Election and Stock Market Performance}

Political climate is one of the important factors that may influence the stock market performance in any countries. Therefore investors, regulatory bodies and researchers are interested to examine market action to reveal any anomalies in the stock market performance that due to any events specifically political events. Chuang and Wang (2009) explain that stock markets are one of important benchmarks to measure the economic performance of a country. There are many factors that may influence the stock market performance. For example, change in monetary and fiscal policy, political, exchange rate and commodity price. Therefore, any events, news, change of policy that may impact the stock market.

Previous studies on political theme and stock market performance focussing into a few different issues. For example, there are few studies investigate the influence of political cycle and leadership role on the stock market. These kinds of studies claim that political cycle, parties and candidateship may have different effect on the stock market return. Chuang and Wang (2009) conducted a study using US, Japan, Britain and France as a sample, they suggest that political changes are negatively related to the stock market returns. The argument behind the finding is differences between political parties will have different economic agendas, leading to the regular changes in the economic policies where investors see it as significant uncertainties. In that event, the investors undertake conservative stock position to protect their market portfolio. The other study by Kim and Mei (2001) examine the impact of political events on market volatility and return using a component-jump filter and figured that changes in the government administration will somehow affect stock markets. They argue that changes in government will lead towards new economic policies implemented, which driven the revival of uncertainties. The rising behaviour ties caused the investors developed more conservative and discourage investors from taking risks, which leads to negative stock return. Abidin et al. (2010) further discovered the existence on political cycle effects on New Zealand stock market, they found that the stock return is significantly higher under the National government than a labour government.

$\mathrm{Li}$ and Born (2006) examine the presidential election uncertainty and stock returns in the United States. They claim that there is important evidence of the impact of political results on business cycle and stock markets. While, other studies by Wong and McAleer (2009) and, Santa-Clara and Valkanov (2003) investigate whether Democrats or Republicans are good for the stock market by observing presidential election cycles and the stock market. Both of the studies suggest that stock market returns are significantly higher in year 3 and 4 of the cycles compares to year 1 and 2 which is constant with the theory of presidential election cycle. More recent study conducted by Fauvelle-Aymar and Stegmaier (2013) on US stock market also suggest that the stock market reacts more negatively when the Democratic candidate (Barack Obama) has a poll advantage over the Republican candidate (John McCain) than when the Republican candidate has an advantage over the Democratic candidate which this events surely effects the stock market return directly.

Beside that the political cycle and leadership issues, there are also studies on political connected companies' performance and political events. Faccio (2006) estimated the extent of firm's market value creation when a political connection is formed. The reports mentioned an average excess return of $1.94 \%$ whenever a firm's top officer is appointed or elected to a political position and a return of $4.47 \%$ whenever this transpires with a substantial shareholder. While, Wisniewski (2016) investigates whether political connectedness of companies creates wealth for their shareholders. It then moves on to examine whether there is an association between the orientation of the political executive and the phase of the electoral cycle with movements of the stock market index. The study concludes that investment in the political process generates an "extremely high rate of return" for the firm involved and that investors can beat the market by investing thus, reflects elections results. 


\section{Data and Empirical Method}

This study employed the event study methodology in answering the research objective. This method is suggested by Fama, Fisher, Jensen, and Roll (1969). The event study method is used to investigate and infer the impact of certain event on a dependent variable. In this research the event of interest is general election of Malaysia. The main interest of this study is on the $14^{\text {th }} \mathrm{GE}$ which is on $9^{\text {th }}$ May 2018. This study also aims to examine if there are any differences between the latest GE and the previous GE, therefore the previous four Malaysia GE also included in the sample. To investigate the effect of GE on the Malaysian stock market, this research employs an empirical model suggested by Ayuk (2010) and Abidin et al (2010). The event date is Malaysia GE polling day is denoted as T which is mean day 0 (all polling day is on the weekend where the Malaysia stock markets are closed). To examine the effects on stock market before and after the Malaysian GE, the data are collected six months before and up to six months after the polling day.

The daily FBMKLCI data are used in this study and the data are downloaded from Datastream provided by Perpustakaan Tun Dr. Ismail (PTDI) UiTM Johor. While, the other information related to the GE are obtained from the Electoral Commission of Malaysia. The sample period ranges from 1999 to 2018, which covers the latest five GE. Table 1 below, summarizes the details of the event.

Table 1. Malaysia general election

\begin{tabular}{ccc}
\hline No & GE & Date \\
\hline 1. & $14^{\text {th }} \mathrm{GE}$ & $9^{\text {th }}$ May 2018 \\
\hline 2. & $13^{\text {th }} \mathrm{GE}$ & $5^{\text {th }}$ May 2013 \\
\hline 3. & $12^{\text {th }} \mathrm{GE}$ & $8^{\text {th }}$ March 2008 \\
\hline 4. & $11^{\text {th }} \mathrm{GE}$ & $21^{\text {st }}$ March 2004 \\
\hline 5. & $10^{\text {th }} \mathrm{GE}$ & $29^{\text {th }}$ November 1999 \\
\hline
\end{tabular}

This research employs a time series analysis using Ordinary Least Square (OLS) model. The modified equation is as follow:

$$
\mathrm{R}_{\mathrm{t}}=\beta_{0}+\beta_{1} \mathrm{~B}_{t}+\beta_{2} \mathrm{~A}_{t}+\varepsilon_{t}
$$

Where;

$\mathrm{R}_{t}=$ Stock index return at time $t$

$\mathrm{B}_{t}=$ Dummy variable that equal to one for $\mathrm{N}$ trading days before election and zero otherwise

$\mathrm{A}_{t}=$ Dummy variable that equal to one for $\mathrm{N}$ trading days after election and zero otherwise

$\varepsilon=$ error terms

$* \mathrm{~N}$ trading days: $15,30,60 \& 90$

The OLS regression with a dummy variable will allow this study to determine whether the daily stock return could be related to the general elections. The equation is estimated for four different event windows which are 15, 30, 60 and 90 trading days before and after the election date. This estimation was conducted to see the different effect of elections on the daily stock market return (FBMKLCI) at different time frame. Following Liew and Rowland (2016), daily stock market returns is calculate using the formula of:

$$
\mathrm{R}_{\mathrm{t}}=100 \times\left[\ln \left(\mathrm{I}_{t}\right)-\ln \left(\mathrm{I}_{\mathrm{t}-1}\right)\right.
$$

(Equation 2)

Where: $\mathrm{I}_{t}$ and $\mathrm{I}_{t-1}$ are the FBMKLCI at time ${ }_{t}$ and ${ }_{t-l}$ respectively and $\ln$ represents natural logarithm.

\section{Finding and Discussion}

The result of $14^{\text {th }} \mathrm{GE}$ has become a remarkable history for Malaysia political history. The Mahathir's coalition has defeated the Barisan Nasional with 122 seats over a total of 222 Parliament seats. This election results motivate this study to investigate if there is significant effect of $14^{\text {th }}$ GE on FBMKLCI and compared it with the previous GE. Figure 1 below shows the percentage change of FBMKLCI daily return for all five general election covered in this study. The change was calculated for 15,30 and 60 trading days after the election date. The statistics reveal that out of five general election, only two elections pose a positive effect on the stock market which were on $10^{\text {th }}$ and $13^{\text {th }} \mathrm{GE}$. As for the latest 
GE which is $14^{\text {th }}$ (2018), the daily return was decrease by about five percent 15 days after the election and its continued decrease to about nine percent after 30 trading days after the election.

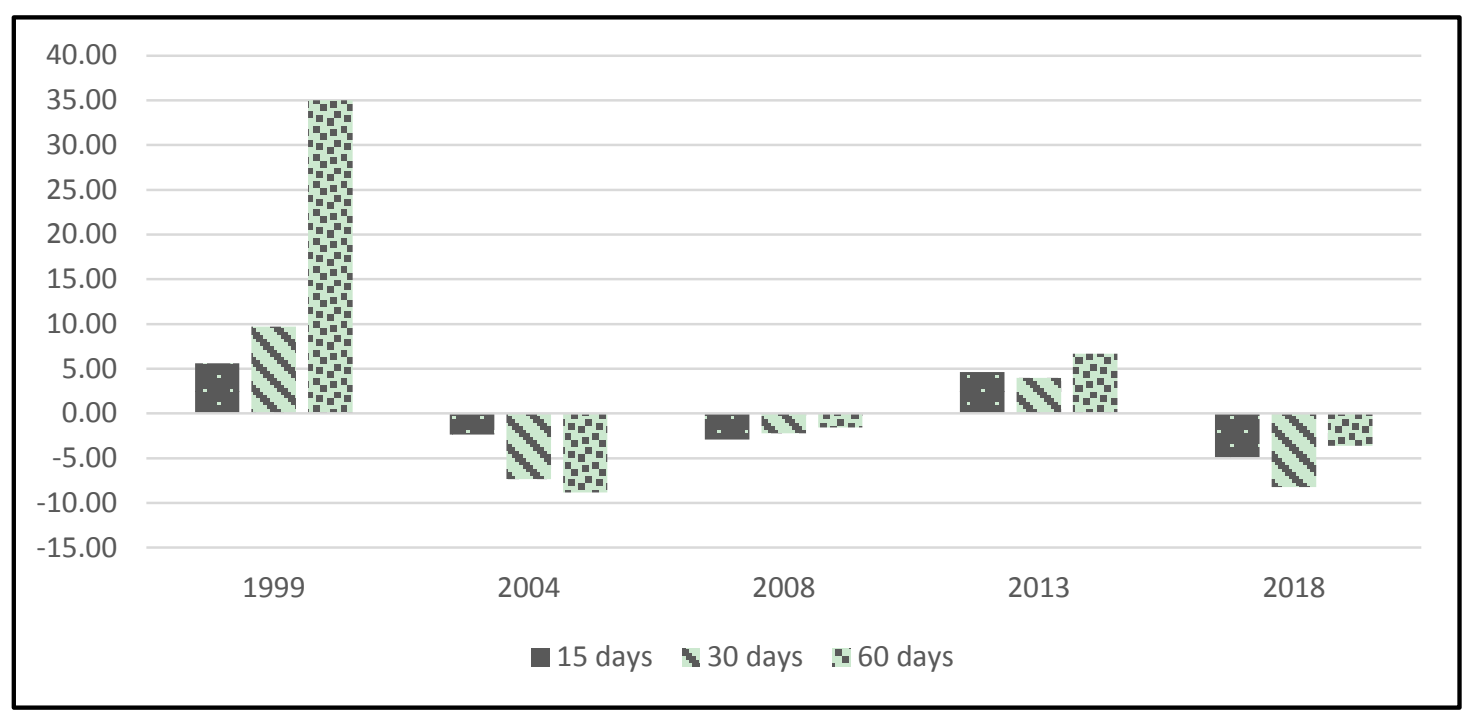

Figure 1. Percentage change in daily return of FBMKLCI after election

Table 2 summarizes the regression results of five different Malaysia general election. This study regresses the stock market return on before and after dummy variables that represent selected trading days window (N: 15, 30, $60 \& 90)$. This study finds an important evidence of the general election effect in the daily stock market return of FBMKLCI. The estimation documented a mixed result for each GE. Particularly for $14^{\text {th }} \mathrm{GE}$, the estimation results reveal a strong significant evidence on after GE effect. The results show a negative significant effect of after GE dummy variable for 15 and 30 trading windows. This result supporting the hypothesis related to election effects on the Malaysia stock market performance as the coefficient value appears to have a significant result at 5 percent level for 15 days trading window and 1 percent level for 30 days trading window. A negative significant coefficient for a dummy after 15 and 30 days of election explain that the FBMKLCI facing a significant decrease as compared before the election period. The daily stock market return was reduced by 0.3614 percent and 0.3343 percent during the first 15 and 30 trading days respectively after the $14^{\text {th }} \mathrm{GE}$. This situation was expected to be happen as investors may feared with many issues for example unfamiliar change of government as Barisan Nasional has ruled since independence (Idris, 2018). However, this scenario only a temporary reaction as for 60 and 90 trading days after the event, this study fails to show any significant evidence. While the estimations fail to find any significant different on daily stock market return for all trading days window before the election. 
Table 2. Malaysian general election effect

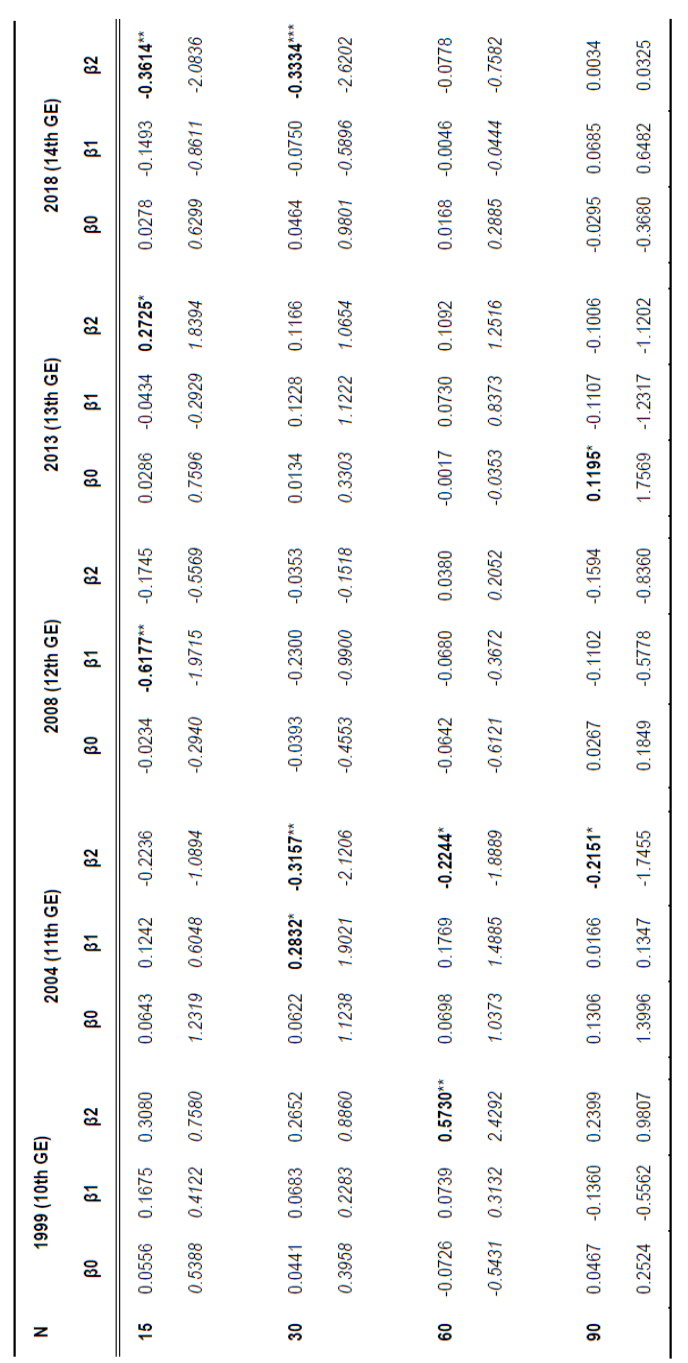

Notes: GE denotes general election. The estimations are based on a sample of 124 trading days before and 124 trading days after each general election. $\mathrm{N}$ denotes number of days for each trading windows. $\beta 0$ is the intercept value, $\beta 1$ is the coefficient value of the dummy variable for $\mathrm{N}$ trading days before the election date and $\beta 2$ is the coefficient value of the dummy variable for $\mathrm{N}$ trading days after the election date. $* * * * *$ and $*$ denote significance at 1,5 and $10 \%$ respectively. Numbers in italic is the t-value.

As compared to the earlier elections which are $10^{\text {th }}, 11^{\text {th }}, 12^{\text {th }}$, and $13^{\text {th }} \mathrm{GE}$, only $11^{\text {th }} \mathrm{GE}$ shows a similar pattern with $14^{\text {th }}$ GE. $11^{\text {th }}$ GE was held on $21^{\text {st }}$ March 2004. This is the first election for the fifth Malaysia Prime Minister, Dato Seri Abdullah Badawi. What make differences between $11^{\text {th }}$ and $14^{\text {th }}$ GE is that Barisan Nasional scored a spectacular victory at $11^{\text {th }}$ GE. Despite this spectacular victory, market had tumble down as the daily market return decrease significantly. The regression results explain that the daily return was significantly lower by $0.3157,0.2244$ and 0.2151 percent during the first 30,60 and 90 trading days respectively after the event date. Compared to the before election effect, the results are totally inverse. All the coefficient having a positive value for all trading days window. However, only one of the dummies is significant at 10 percent significance level. A 30 days trading days before the election found to have a positive significant effect from the election.

As for the other three elections which are $10^{\text {th }}, 12^{\text {th }}$ and $13^{\text {th }} \mathrm{GE}$, only one GE which is $12^{\text {th }}$ GE result does not show any after election effect on the daily market return as this study fails to find any significant results for all trading windows. This results is consistent with Liew and Rowland (2016). The $12^{\text {th }}$ GE only appear to have an impact on the daily market return 15 days before the election date. The coefficient value exhibits a negative before election effect. The 
daily return was lower by 0.6177 percentage point as compared to the normal trading days. While for the $10^{\text {th }}$ and $13^{\text {th }}$ $\mathrm{GE}$, the results show there is a positive effect of election on the daily market return for selected trading windows. In $10^{\text {th }} \mathrm{GE}$, the investors have been positively reacting to the election results. All the coefficient value for a dummy that represent after election event appear to have a positive value. The market was correspondent to have extra return as compared before the election period. The daily return for 60 trading days after the event date show an increase of 0.5729 percentage unit and it is statistically significant at 5 percent significant level. While for $13^{\text {th }} \mathrm{GE}$, there is a temporary short run effects as the estimations only show a positive significant result for a 15 trading days window dummy after the event date. This indicates that the daily stock market return of 15 days after $13^{\text {th }} \mathrm{GE}$ is significantly higher as compared to the before election days. Both $10^{\text {th }}$ and $13^{\text {th }} \mathrm{GE}$, there is no statistically significant evidence for before election effect. These indicate that investors act calmly and do not make any speculation on the election. The market does not attempt to incorporate the election news into price before the election occurs.

\section{Conclusion}

The $14^{\text {th }}$ general election remarks its own national history. The opposition party (Pakatan Harapan) has defeated the all-time winner (Barisan Nasional). For the past 13 general election, the Barisan Nasional managed to conquer the results and managed to set up a government of Malaysia. However, the $13^{\text {th }} \mathrm{GE}$ had given signal that the opposition party were eying to winning the election as they able to make the election result very tight by won about 53 percent of the vote.

Many studies such as (Abidin et al., 2010; Colón-De-Armas et al., 2017; Liew \& Rowland, 2016; Wisniewski, 2016) hypothesize that political event specifically election having a significant effect on the stock market performance. This current study provides the latest empirical evidence on Malaysia general election and its effect on stock market performance. This study takes a sample from the most recent five general election held in Malaysia. The estimation results of Ordinary Least Square regression model provide important evidence related to the effect of election before and after the event date. The results reveal that there is significant before election effect on stock market for $11^{\text {th }}$ and $12^{\text {th }} \mathrm{GE}$. However, there is a contrast effect as in $11^{\text {th }} \mathrm{GE}$ before election effect show a positive significant value while, in $12^{\text {th }} \mathrm{GE}$, the return appeared to be lower 15 days before the election. Four election exhibits a statistically significant after election effect. Two of it $\left(10^{\text {th }}\right.$ and $\left.13^{\text {th }} \mathrm{GE}\right)$, the stock market reaction was positive after the election and the stock market was significantly negatively affected by the election in $11^{\text {th }}$ and $14^{\text {th }}$ GE. This important evidence prove that the investors may seek for abnormal return before and after important political event such as general election. The investors need to pay attention and some research on the current political scenario and not to ignore the importance of macroeconomics variables. As recommendation for future study, the researchers may test different time frame for the trading window, as the effect might be different. Adding the other importance macroeconomic variables also will add more value to the finding.

\section{References}

Abidin, S. Z., Old, C., \& Martin, T. (2010). Effects of New Zealand general elections on stock market returns.

Ayuk, A. B. O. (2010). US Presidential Elections: An International Financial Market Perspective. Alliant International University, Marshall Goldsmith School of Management....

Chuang, C.-C., \& Wang, Y.-H. (2009). Developed stock market reaction to political change: a panel data analysis. Quality \& Quantity, 43(6), 941-949.

Colón-De-Armas, C., Rodriguez, J., \& Romero, H. (2017). Investor sentiment and US presidential elections. Review of Behavioral Finance, 9(3), 227-241. https://doi.org/10.1108/rbf-02-2016-0003

Faccio, M. (2006). Politically connected firms. American Economic Review, 96(1), 369-386.

Fama, E. F., Fisher, L., Jensen, M. C., \& Roll, R. (1969). The adjustment of stock prices to new information. International Economic Review, 10(1), 1-21.

Fauvelle-Aymar, C., \& Stegmaier, M. (2013). The stock market and US presidential approval. Electoral Studies, 32(3), 411-417.

Floros, C., \& Floros, C. (2008). The influence of the political elections on the course of the Athens Stock Exchange 1996-2002. Managerial Finance, 34(7), 479-488. https://doi.org/10.1108/03074350810874433

Idris, N. (2018). After Shocking Election Result, Malaysia may be Headed for Market Volatility, Economic Change.

Keef, S. P., \& Roush, M. L. (2002). Presidential administration and day-of-the-week effects in the Standard \& Poor's 500 stock index. Review of Accounting and Finance, 1(4), 13-27. https://doi.org/10.1108/eb026994 
Kim, H. Y., \& Mei, J. P. (2001). What makes the stock market jump? An analysis of political risk on Hong Kong stock returns. Journal of International Money and Finance, 20(7), 1003-1016.

Kithinji, A., \& Ngugi, W. (2009). Stock market performance before and after general elections: a case of the Nairobi stock exchange.

Li, J., \& Born, J. A. (2006). Presidential election uncertainty and common stock returns in the United States. Journal of Financial Research, 29(4), 609-622.

Liew, V. K.-S., \& Rowland, R. (2016). The effect of Malaysia general election on stock market returns. SpringerPlus, 5(1), 1975.

Mattozzi, A. (2004). Can we insure against political uncertainty? Evidence from the US stock market.

Oehler, A., Walker, T. J., \& Wendt, S. (2013). Effects of election results on stock price performance: evidence from 1980 to 2008. Managerial Finance, 39(8), 714-736. https://doi.org/10.1108/MF-May-2012-0126

Pantzalis, C., Stangeland, D. A., \& Turtle, H. J. (2000). Political elections and the resolution of uncertainty: the international evidence. Journal of Banking \& Finance, 24(10), 1575-1604.

Santa-Clara, P., \& Valkanov, R. (2003). The presidential puzzle: Political cycles and the stock market. The Journal of Finance, 58(5), 1841-1872.

Waggle, D., \& Agrrawal, P. (2018). Is the "sell in May and go away" adage the result of an election-year effect?. Managerial Finance, 44(9), 1070-1082. https://doi.org/10.1108/mf-12-2017-0505

Wisniewski, T. P. (2016). Is there a link between politics and stock returns? A literature survey. International Review of Financial Analysis, 47, 15-23.

Wong, W.-K., \& McAleer, M. (2009). Mapping the Presidential Election Cycle in US stock markets. Mathematics and Computers in Simulation, 79(11), 3267-3277. 